\title{
Evaluating chemical signatures in a coastal upwelling region to reconstruct water mass associations of settlement-stage rockfishes
}

\author{
Sarah G. Wheeler ${ }^{1, *}$, Ann D. Russell ${ }^{2}$, Jennifer S. Fehrenbacher ${ }^{2}$, Steven G. Morgan ${ }^{3}$ \\ ${ }^{1}$ Graduate Group in Ecology at the University of California at Davis and San Diego State University, 5500 Campanile Dr, \\ San Diego, California 92184-4614, USA \\ ${ }^{2}$ University of California, Davis, One Shields Ave, Davis, California 95616, USA \\ ${ }^{3}$ Bodega Marine Laboratory, University of California, Davis, 2099 Westside Dr, Bodega Bay, California 94923-0247, USA
}

\begin{abstract}
Characterizing the behavior of larvae prior to settlement is integral to understanding population dynamics because coastal oceanography may facilitate or limit settlement. Otolith microchemistry can be used to determine patterns of fish movement, although there is a limited understanding of how this tool can be applied in coastal marine systems. Our goal in this study was to evaluate the application of otolith microchemistry to characterize water mass associations of settlement-stage marine fish in a coastal upwelling region using a 3-step approach. First, we characterized seawater chemistry of coastal water mass types across multiple years, finding differences in the chemical signatures of strong upwelling, weak upwelling, and relaxation events. Second, we experimentally determined the effect of temperature on the partitioning of trace elements in otoliths for 2 rockfishes (Sebastes spp.) to find that the effect of temperature on otolith partition coefficients was element- and species-specific. Finally, we compared coeval changes in seawater and otolith chemistry of settlement-stage rockfishes that were exposed to naturally variable conditions over an upwelling-relaxation cycle. We subsequently evaluate whether laser ablation inductively coupled plasma mass spectrometry effectively measures otolith chemistry over ecologically relevant time scales. We discovered that elemental concentrations in otoliths respond rapidly to changes in seawater chemistry and reflect equivalent proportional changes. This study provides evidence that elemental signatures are valuable tools for reconstructing larval histories of marine fish in coastal upwelling regions.
\end{abstract}

KEY WORDS: Barium - Laser ablation - Inductively coupled plasma mass spectrometry · ICP-MS · Otolith · Seawater

\section{INTRODUCTION}

The elemental compositions of seawater and fish otoliths have numerous applications to ecological research and fisheries management (Campana 1999, Campana \& Thorrold 2001, Thorrold et al. 2007, Elsdon et al. 2008). Otolith chemistry research capitalizes on differences in the chemical composition of environments to reconstruct fish movements, and heterogeneity in trace elements in freshwater and

*Corresponding author: sarahgracewheeler@gmail.com estuarine environments has led to a substantial body of research in these systems (Campana \& Thorrold 2001, Gillanders 2005, Elsdon \& Gillanders 2006). The validation and application of chemical tags in marine fishes is relatively understudied (Sturrock et al. 2012). However, chemical gradients between nearshore and offshore environments and water masses have revealed fish cross-shelf movements (Kingsford et al. 2009), larval dispersal or migrations (Swearer et al. 1999, Hamilton et al. 2008), and settle-

(C) The authors 2016. Open Access under Creative Commons by Attribution Licence. Use, distribution and reproduction are unrestricted. Authors and original publication must be credited. 
ment (Hamilton \& Warner 2009). There is a critical need to validate the potential application of trace element chemistry in marine larval fish because there are few other techniques available to tag larvae or reconstruct their environmental conditions. In addition, the larval environment plays an important role in determining year-class strength, particularly in systems where upwelling influences feeding conditions and settlement (Cushing 1990, Houde 2008, Caselle et al. 2010a,b). Understanding chemical signatures in coastal systems is complicated by the inherent variability of larval environments, such as changing chemical environments or ambient temperatures associated with upwelling. In upwelling systems, successful interpretation of otolith chemistry requires knowledge of how temperature may modify the incorporation of elements into otoliths.

In this study, we used field and laboratory studies to validate the application of otolith chemistry analysis to evaluate short-term residencies of larval marine rockfishes (Sebastes caurinus, S. flavidus, and $S$. melanops) in waters associated with upwelling and relaxation cycles. We established the link between geochemistry and upwelling by measuring seawater $\mathrm{Mg} / \mathrm{Ca}, \mathrm{Sr} / \mathrm{Ca}$, and $\mathrm{Ba} / \mathrm{Ca}$ ratios during strong upwelling, weak upwelling, and relaxation events over $4 \mathrm{yr}$, using temperature and wind speed as independent indicators of upwelling. We then evaluated the effect of temperature on $\mathrm{Mg} / \mathrm{Ca}, \mathrm{Sr} / \mathrm{Ca}$, and $\mathrm{Ba} / \mathrm{Ca}$ ratios into otoliths of fish grown in the laboratory over a range of controlled temperatures. Finally, we measured otolith and seawater chemistry in a controlled laboratory environment during an upwelling-relaxation cycle, to evaluate how well otolith chemistry reflects the chemical environment over ecologically relevant time scales.

We used $\mathrm{Sr}, \mathrm{Mg}, \mathrm{Ca}$ and $\mathrm{Ba}$ to characterize seawater types because the concentrations of these elements are modified by mixing or biological processes that occur in coastal upwelling systems (Lea et al. 1989, Coffey et al. 1997, de Villiers 1999, Hunter \& Boyd 1999). Sr, Mg, and Ca are considered quasiconservative elements with oceanic inventories that are large relative to riverine input; however, involvement in biological and (for $\mathrm{Ca}$ and $\mathrm{Mg}$ ) hydrothermal processes results in slight differences in their vertical and spatial distributions, which may result in chemical signatures of surface and intermediate waters. In the northeast Pacific, salinity-normalized $\mathrm{Sr}$ and $\mathrm{Sr} / \mathrm{Ca}$ ratios are lowest in mid-latitude, nutrient-poor surface waters. In nutrient-rich equatorial and high latitude surface waters, they are enriched by 0.7 and $1.5 \%$ respectively over the low-latitude concentra- tions (de Villiers 1999). This distribution is likely caused by surface blooms of Acantharia skeletons $\left(\mathrm{SrSO}_{4}\right)$ and calcifying organisms in surface waters, which sink and dissolve at depth (de Villiers 1999). $\mathrm{Ca}$ is slightly depleted in warm western Pacific surface waters (by $\sim 1.5 \%$ ) relative to cold surface and intermediate depth waters $(\sim 1.5-3 \mathrm{~km}$ depth) due to removal by calcifiers (Tsunogai \& Watanabe 1981). Low-temperature hydrothermal circulation enriches intermediate-water $\mathrm{Ca}$ concentrations in the near vicinity of ocean ridges by up to $\sim 1 \%$ and depletes Mg by about the same fractional amount (de Villiers \& Nelson 1999). The vertical and spatial variability in $\mathrm{Sr}, \mathrm{Ca}$ and $\mathrm{Mg}$ concentrations suggest that the ratios may serve as indicators of coastal circulation patterns and biological activity associated with upwelling.

In contrast to the slight vertical changes seen in $\mathrm{Sr}$, $\mathrm{Ca}$, and $\mathrm{Mg}$, barium profiles in seawater are generally depleted in surface waters (to $\sim 40 \mathrm{nmol} \mathrm{kg}^{-1}$ ) and enriched in intermediate waters (to $\sim 150 \mathrm{nmol} \mathrm{kg}{ }^{-1}$ ) (Chan et al. 1976), caused by formation of barite $\left(\mathrm{BaSO}_{4}\right)$ in surface waters and its dissolution at depth (Monnin et al. 1999, Griffith \& Paytan 2012). This pattern can vary spatially and temporally. Locations with strong upwelling activity have elevated $\mathrm{Ba} / \mathrm{Ca}$ ratios in surface waters (Woodson et al. 2013). Intense transient plankton blooms can significantly deplete surface Ba concentrations below $40 \mathrm{nmol}$ $\mathrm{kg}^{-1}$ (Esser \& Volpe 2002). In addition, Ba concentrations in coastal waters near estuaries can be considerably higher than in the open ocean or in coastal waters away from rivers. Within estuaries, Ba attached to suspended aquifer particles is released during mixing between fresh and salty waters, effectively pumping dissolved Ba into estuarine waters ( $\mathrm{Li}$ \& Chan 1979, Coffey et al. 1997, Moore \& Shaw 2008). In a well-studied Pacific Northwest estuary, these processes enriched Ba concentrations in water delivered to the ocean by $170 \%$ relative to riverine concentrations (Colbert \& McManus 2005).

The chemical composition of coastal waters is determined by the relative amounts of nutrient-depleted surface waters, upwelled water, and brackish water entering the ocean through estuaries. In principle, mixtures of these water types will produce diagnostic combinations of $\mathrm{Mg} / \mathrm{Ca}, \mathrm{Sr} / \mathrm{Ca}$, and $\mathrm{Ba} / \mathrm{Ca}$ ratios, labeling the source water and providing a useful tool for ecological research in coastal systems. Multiple tracers are required to establish the elemental signature of these water types because any one tracer may vary for several different reasons, as discussed in the previous paragraphs. 
There is growing evidence that chemical signatures during upwelling are reflected in fish otoliths, indicating the potential application of otolith chemistry to evaluate exposure to upwelling conditions in marine fish. The $\mathrm{Ba} / \mathrm{Ca}$ ratio in otoliths $\left(\mathrm{Ba} / \mathrm{Ca}_{\text {Otolith }}\right)$ is likely an effective tracer of Ba-rich upwelled waters (Volpe \& Esser 2002, Kingsford et al. 2009, Walther et al. 2013, Woodson et al. 2013). For instance, it has been estimated that up to $98 \%$ of $\mathrm{Ba} / \mathrm{Ca}_{\text {Otolith }}$ is derived from ambient water (Walther \& Thorrold 2006), and relative to other elements, the short turn-over time of $\mathrm{Ba}$ in the bodies of fishes indicates a strong potential for $\mathrm{Ba} / \mathrm{Ca}_{\text {Otolith }}$ to reflect short-term changes in the $\mathrm{Ba}$ concentration of the ambient water (Sturrock et al. 2012). Several studies have recognized the potential for otolith chemistry to evaluate fish associations with upwelling regions or water masses; few studies, however have validated these signatures in otoliths or applied them in ecological research (Patterson et al. 2004, Kingsford et al. 2009, Nishimoto et al. 2010, Lin et al. 2013, Woodson et al. 2013).

The ability to discern residence in upwelling currents is valuable for understanding the role these currents play in fish movement and larval settlement. In coastal systems, distinct upwelling and relaxation seasons are produced by seasonal variability in wind strength and direction. Peak upwelling season occurs from April to June and is characterized by persistent and strong northwesterly winds that drive Ekman currents (García-Reyes \& Largier 2012). During the spring, these offshore surface currents may slow or halt during wind relaxation events (García-Reyes \& Largier 2012). The settlement of marine fishes, including winter-spawning rockfishes, coincides with the spring upwelling season (Love et al. 2002), indicating that these fishes likely experience persistent upwelling conditions that strengthen or weaken in response to wind stress. Conversely, spring-spawning rockfishes settle from late June to September during the relaxation season (Love et al. 2002). Summer relaxation conditions prevail as wind stress weakens and sea surface temperatures increase. Strong upwelling of cold nutrient-rich water is rare or absent during the relaxation season (García-Reyes \& Largier 2012). Given the seasonal patterns in oceanography and settlement, we believe it is valuable to compare water chemistry among strong upwelling, weak upwelling and relaxation water mass types.

Determining fish residencies in upwelling waters depends on distinct chemical signatures of coastal water masses and validation that these signatures are reliably incorporated into fish otoliths. In general, some elements are incorporated into otoliths in pro- portion to ambient environmental concentrations (Campana \& Thorrold 2001, Elsdon et al. 2008). However, diet, temperature and salinity can influence the incorporation of elements into otoliths, and these effects may be species or life-stage specific (Elsdon \& Gillanders 2002, Bath Martin et al. 2004, Elsdon et al. 2008, Miller 2009, 2011, Walther et al. 2010). The effect of temperature on otolith chemistry is especially important to consider in marine systems because temperature may vary by as much as $9^{\circ} \mathrm{C}$, unlike salinity, which exhibits minimal variation. Upwelling and relaxation cycles modify seawater temperature, in addition to changing the chemical environment. Isolating the effect of temperature over the temporal and environmental gradients specific to coastal upwelling regions may improve ecological interpretation of chemical signatures in otoliths.

Additional challenges to using otolith microchemistry in marine fishes stem from the spatial resolution, sensitivity, and precision of the analytical tools that measure otolith chemistry (Hoover et al. 2012). Upwelling and relaxation events occur over relatively short time-scales (days), and larval transport from offshore environments to nearshore nursery grounds occurs over comparable time scales (Robertson et al. 1999, Caselle et al. 2010b). The time scales of oceanographic and behavioral characteristics demand both high-resolution sampling and precise analytical techniques to characterize trace element chemistry and larval residence in upwelling or relaxation water masses.

\section{MATERIALS AND METHODS}

\section{Seawater sampling and analysis}

From 2009 to 2012, water samples were collected approximately every $2 \mathrm{~d}$ from early April to late July. All samples were collected from the Bodega Marine Laboratory, University of California, Davis, flowthrough seawater system. The seawater system intake pipe is located at $3 \mathrm{~m}$ depth and $73 \mathrm{~m}$ offshore from the opening of Horseshoe Cove in Bodega Bay, California. This pipe connects to a series of 3 tanks with weirs and polyethylene mesh to filter out large solids before water is transported to holding tanks. Seawater is gravity fed from the holding tanks to the laboratory piping and aquaria system, where samples were collected. We collected $12 \mathrm{ml}$ of seawater using syringes, filtered through a $45 \mu \mathrm{m}$ membrane filter and preserved with Optima grade hydrochloric acid (resulting in $0.2 \%$ acid in the sample) under 
HEPA-filtered laminar-flow conditions. Syringes, filters, and centrifuge tubes were leached in $1 \mathrm{M} \mathrm{HCl}$ at $60^{\circ} \mathrm{C}$ for $12 \mathrm{~h}$, followed by thorough rinsing in double-deionized water and a pre-rinse with the seawater sample. Replicate water samples were collected on each sampling day in 2011 and 2012 (n = 2-6). Replicate samples were unavailable in 2009 and 2010 because samples were opportunistically acquired. In these 2 years, sampling did not continue past 30 June. Over the $4 \mathrm{yr}$ of the study, a total of 254 water samples was collected, representing $125 \mathrm{~d}(\mathrm{n}=125)$.

For each water sample, the oceanographic conditions associated with the day of collection were obtained using the University of California, Davis, Bodega Ocean Observing Node database (http:// bml.ucdavis.edu/boon). To characterize upwelling conditions for each sample, we averaged hourly sea surface temperature (SST) and calculated alongshore wind speeds (AWS) averaged over $3 \mathrm{~d}$ prior to collection, an ecologically relevant temporal scale over which wind conditions drive water movement (Bakun \& Nelson 1991). For each year, a hierarchical cluster analysis using the variables SST and AWS was used to categorize water samples into oceanographic water mass types reflecting upwelling strength. The 3 primary groups generated from the cluster analysis were subsequently characterized using group mean SST and AWS as diagnostic indicators of strong upwelling, weak upwelling, and relaxation events. Indices of freshwater input were excluded from the cluster analysis to characterize water masses, because freshwater flow and elemental ratios in seawater were not correlated in any year of the study (Text S1 in the Supplement at www.int-res.com/ articles/suppl/m550p191_supp.pdf).

Water samples were analyzed for $\mathrm{Ca}, \mathrm{Sr}, \mathrm{Mg}$, and Ba by the Interdisciplinary Center for Plasma Mass Spectrometry at the University of California, Davis (http://icpms.ucdavis.edu) using an Agilent 7500CE inductively coupled plasma mass spectrometer (Agilent Technologies) (see Text S2 in the Supplement for a detailed description of analytical methods). Limits of detection (LOD) were calculated automatically using Chemstation G1834B, B.03.04 software. The LOD is defined here as $3 \sigma B / a$, where ' $\sigma B$ ' is the standard deviation of the replicate analyses of the analyte (counts per second, cps)/internal standard (cps) ratio of the calibration blank, and $a$ is the coefficient from the internal standard corrected calibration curve's regression equation: $y=a x+$ blank. Raw data were corrected for drift using a single sample re-analyzed multiple times over the course of the run. The driftcorrected elemental concentrations of these re-ana- lyzed samples also provided a measure of within-run precision (expressed as relative standard deviation [RSD], \% of mean). Mean within-run precision was $<2 \%$ (for $\mathrm{Mg}, \mathrm{Ca}$, and $\mathrm{Sr}$ ) and $<12 \%$ (for $\mathrm{Ba}$ ) over 4 runs (Table S2 in the Supplement). On the last run, Ba precision was $18 \%$. Sample-to-sample precision of elemental ratios (also expressed as RSD) was determined using a subset of samples (17 out of $125 \mathrm{~d})$ for which 3 replicates were collected on the same day. The mean precision of sample replicates was $<3 \%$ (for $\mathrm{Mg} / \mathrm{Ca}$ and $\mathrm{Sr} / \mathrm{Ca}$ ) and $<9 \%$ for Ba/Ca.

Samples collected in each of the $4 \mathrm{yr}$ were pooled in a 2-factor PERMANOVA with year and water type as factors and a significance level of $\mathrm{p}<0.05$. In our analysis, we used elemental ratios to $\mathrm{Ca}$, as opposed to raw concentrations, to eliminate any effect of dilution on elemental signatures (for a detailed explanation see Text S3 in the Supplement). The PERMANOVA used $\mathrm{Mg} / \mathrm{Ca}, \mathrm{Sr} / \mathrm{Ca}$, and $\mathrm{Ba} / \mathrm{Ca}$ ratios as predictor variables to compare the chemical signatures of strong upwelling, weak upwelling, and relaxation water mass types. Pairwise comparisons were conducted among water mass types. Statistical analyses used the average value of replicate water samples and employed PRIMER 6 ver. 6.1.13 and PERMANOVA+ ver. 1.0.3 statistical software (PREMIER Enterprises). A SIMPER analysis was conducted to identify the primary element driving the dissimilarity among water mass types.

\section{Experimental design}

Fish collection

Recently settled rockfishes ( $\sim 3$ to 4 mo old) were seined from eelgrass beds in Bodega Harbor, California (collections within $100 \mathrm{~m}$ of $38^{\circ} 18^{\prime} 19^{\prime \prime} \mathrm{N}$, $\left.123^{\circ} 03^{\prime} 28^{\prime \prime} \mathrm{W}\right)$. Sample sizes for experiments were determined by collection success. All fish were collected within $3 \mathrm{wk}$ to minimize variability in fish size. We used 2 species of winter spawning rockfish, the copper rockfish Sebastes caurinus and rockfishes in the black and yellowtail species complex ( $S$. flavidus and $S$. melanops, collectively called BY rockfish). BY rockfish are genetically similar and morphologically indistinguishable at early life-stages (Love et al. 2002), and we assumed negligible differences in their responses to environmental conditions given the shared genetic and phenotypic characteristics. Upon collection, fish were transported to the Bodega Marine Laboratory and housed prior to experimentation for no more than $2 \mathrm{wk}$ in aquaria receiving flow- 
through seawater and frozen brine shrimp ad libitum. All fish collection, handling, and experimental procedures adhered to the University of California, Davis, Institutional Animal Care and Use Committee standards (Protocol No. 16448). After experimentation, fish were euthanized using a concentration of $300 \mathrm{mg} \mathrm{l}^{-1} \mathrm{MS}-222$ prior to otolith analysis. Immediately following euthanasia, right and left sagittal otoliths were extracted, cleaned, and stored following protocols outlined by Bath et al. (2000).

Temperature effect on otolith partition coefficients

We measured the effects of temperature on the incorporation of elements into otoliths of juvenile rockfishes by experimentally rearing fish at temperatures typical of upwelling-relaxation cycles $\left(8-15^{\circ} \mathrm{C}\right.$; coldest during strong upwelling). We crossed copper and BY rockfishes orthogonally with 3 temperatures: 8.5, 11 , and $14^{\circ} \mathrm{C}$, with 3 replicate tanks $(\mathrm{n}=3)$ for each

Table 1. Number of copper Sebastes caurinus and BY (black S. flavidus and yellowtail $S$. melanops species complex) rockfish reared in replicate tanks under controlled temperature conditions and their otoliths analyzed with laser ablation inductively coupled plasma mass spectrometry

\begin{tabular}{|c|c|c|c|c|c|c|}
\hline \multirow{2}{*}{$\begin{array}{l}\text { Temperature } \\
\left({ }^{\circ} \mathrm{C}\right) \\
8.5\end{array}$} & \multicolumn{3}{|c|}{$\begin{array}{l}\text { No. of copper rockfish } \\
\text { Tank } 1 \text { Tank } 2 \text { Tank } 3\end{array}$} & \multicolumn{3}{|c|}{$\begin{array}{l}\text { No. of BY rockfish } \\
\text { Tank } 1 \text { Tank } 2 \text { Tank } 3\end{array}$} \\
\hline & 4 & 3 & 3 & 6 & 5 & 5 \\
\hline 11 & 3 & 4 & 3 & 6 & 5 & 6 \\
\hline 14 & 4 & 4 & 3 & 6 & 5 & 5 \\
\hline
\end{tabular}

treatment. Six 381 aquaria were placed in each of 3 temperature control rooms, with 3 tanks designated for each species. All tanks were simultaneously filled with filtered seawater acquired from the Bodega Marine Laboratory flow-through seawater system, a method we previously determined to have negligible inter-tank variability of Sr/Ca $\left(<0.10 \mathrm{mmol} \mathrm{mol}{ }^{-1}\right)$

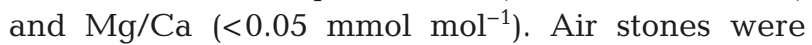
placed in each tank, and all tanks were covered with plastic to minimize evaporation. Tanks were allowed $3 \mathrm{~d}$ to equilibrate to temperature conditions prior to the addition of 3 to 4 copper or 5 to 6 BY rockfish per tank (standard length [SL] range: 23.5-39.9 and 31.1-47.3 mm, respectively) (Table 1). HOBO Tidbit v2 temperature loggers (Onset HOBO Data Loggers) were placed within each tank to measure water temperature over the experimental period. Temperature control rooms maintained seawater tank temperatures within reasonable proximity of target values $($ mean $\pm \mathrm{SD}): 8.61 \pm 0.029,11.09 \pm 0.125$, and $13.74 \pm$ $0.086^{\circ} \mathrm{C}$. Elemental concentrations within experimental aquaria reflected concentrations measured in our study region and did not significantly differ among treatments over the experimental period for $\mathrm{Mg} / \mathrm{Ca}, \mathrm{Sr} / \mathrm{Ca}$, and $\mathrm{Ba} / \mathrm{Ca}$ (Tables 2 \& 3).

Two water samples were collected from each tank every $2 \mathrm{~d}$ of the experiment, and prepared and analyzed as described in 'Materials and methods: Seawater sample collection and analysis'. Fish were starved for $2 \mathrm{~d}$ prior to experimentation to minimize ammonia concentrations in aquaria. During

Table 2. Mean and SD (in parentheses) $\mathrm{Mg} / \mathrm{Ca}, \mathrm{Sr} / \mathrm{Ca}$ and $\mathrm{Ba} / \mathrm{Ca}$ (a) ratios of seawater and rockfish otoliths and (b) partition coefficients measured in replicate tanks under controlled temperature conditions. BY: black and yellowtail species complex

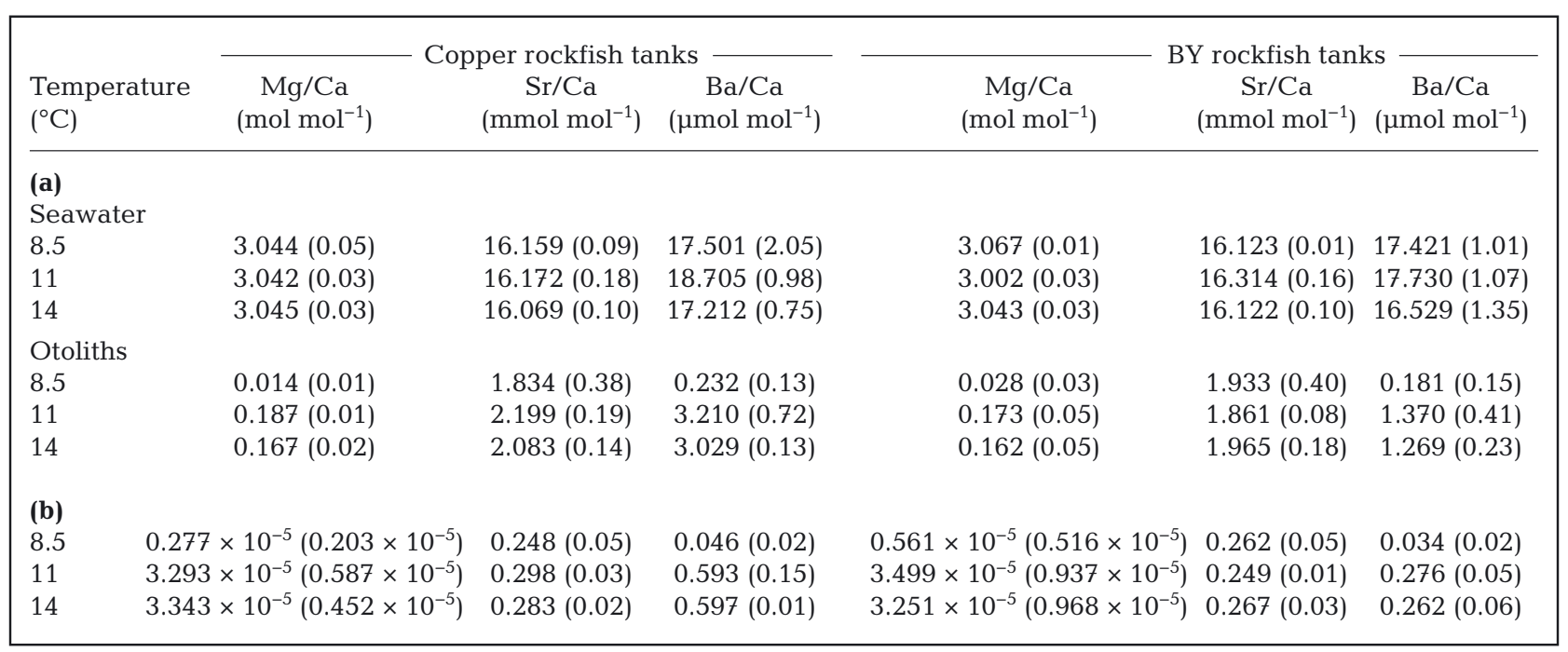


Table 3. ANOVA comparing seawater $\mathrm{Mg} / \mathrm{Ca}, \mathrm{Sr} / \mathrm{Ca}$, and $\mathrm{Ba} / \mathrm{Ca}$ ratios in aquaria with copper and BY (black and yellowtail species complex) rockfish at $8.5,11$, or $14^{\circ} \mathrm{C}$

\begin{tabular}{|lcccccccc|}
\hline \multirow{2}{*}{ Source of variation } & df & \multicolumn{3}{c}{$\mathrm{Mg} / \mathrm{Ca}$} & \multicolumn{3}{c|}{$\mathrm{Sr} / \mathrm{Ca}$} & \multicolumn{3}{c|}{$\mathrm{Ba} / \mathrm{Ca}$} \\
& & $F$ & $\mathrm{p}$ & $F$ & $\mathrm{p}$ & $F$ & $\mathrm{p}$ \\
\hline Species & 1,12 & 0.03 & 0.87 & 0.70 & 0.42 & 1.26 & 0.28 \\
Temperature & 2,12 & 1.88 & 0.20 & 2.22 & 0.15 & 0.46 & 0.64 \\
Temperature $\times$ Species & 2,12 & 3.23 & 0.08 & 1.27 & 0.32 & 0.93 & 0.42 \\
& & & & & & & & \\
\hline
\end{tabular}

Otolith and seawater chemistry during an upwelling-relaxation cycle

The objective of this experiment was to simulate the variable oceanographic conditions experienced by early lifestage rockfishes and the extent to which otolith chemistry reflects variability in seawater chemistry during an upwelling and relaxation cycle. We assessed synchrony in water and

the subsequent $10 \mathrm{~d}$ experimental period, fish were reared without food to reduce any influence of diet or food addition on trace element concentrations in otoliths or seawater. One copper rockfish in tank 2 of the $8.5^{\circ} \mathrm{C}$ treatment did not survive the experimental period and was excluded from laser ablation inductively coupled plasma mass spectrometry (ICP-MS) analyses. It is possible that experimental conditions may have increased fish stress and, possibly, the incorporation of elements into otoliths. While previous studies have found stress to affect otolith Sr/Ca (Kalish 1992, Mohan et al. 2014, Sturrock et al. 2014), we found no difference in the partitioning of Sr/Ca into otoliths among treatments (see 'Results'), and $\mathrm{Sr} / \mathrm{Ca}$ ratios of fish reared in the temperature experiment were similar to those measured in fish reared under natural feeding and temperature conditions. Thus, stress may have had a negligible effect on elemental ratios to $\mathrm{Ca}$ in otoliths relative to the effect of ambient seawater chemistry.

The relationship between water and otolith trace metal composition was expressed as the empirical partition coefficient $\left(D_{\mathrm{Metal} / \mathrm{Ca}}\right)$ (Morse \& Bender 1990), where

$$
[\text { Metal/Ca }]_{\text {Otolith }}=D_{\text {Metal }}[\text { Metal/Ca }]_{\text {Water }}
$$

This approach was used to reveal changes in elemental uptake in otoliths among temperature treatments and species.

We used a 2-factor ANOVA to test for differences in elemental ratios to $\mathrm{Ca}$ and $D_{\text {Metal }}$ among temperature treatments and species. The assumptions of equal variances among groups and normality were evaluated using Levene's and Shapiro Wilk Tests; both assumptions were met. Post hoc pairwise comparisons were made using a Tukey's HSD test. To evaluate whether individual growth rates influenced $D_{\text {Metal }}$, we scaled $D_{\text {Metal/Ca }}$ to SL (in $\mathrm{mm}$ ) of each fish, which we used as a proxy for individual growth ( $D_{\text {Metal }} / \mathrm{SL}$ ). $D_{\text {Metal }} /$ SL values were analyzed using a 2factor ANOVA to test for differences among temperature treatments and species. otolith chemistries by comparing the proportional change in otolith elemental concentrations relative to the proportional changes measured in seawater. Juvenile copper and BY rockfish (SL range: 38.0-53.8 and 38.3-45.1 $\mathrm{mm}$, respectively) were reared in aquaria receiving filtered flow-through seawater at rates of $41 \mathrm{~min}^{-1}$. Two copper or $5 \mathrm{BY}$ rockfish were placed within each replicate tank for each species ( $\mathrm{n}=3$ tanks per species, total no. of copper rockfish sampled $=6$, total no. of BY rockfish sampled $=15$ ). Fish were acclimated to aquaria for $2 \mathrm{~d}$ prior to a $31 \mathrm{~d}$ period. Each day, tanks were cleaned of algal growth and detritus following a $1 \mathrm{~h}$ period of feeding frozen brine shrimp. Two water samples were collected from each tank every $2 \mathrm{~d}$ and subsequently analyzed following the protocol outlined in 'Material and methods: Seawater sample collection and analysis'.

\section{Otolith preparation}

Otoliths were sanded in the sagittal plane to reveal daily growth rings. Deposition of daily growth bands has been validated for several larval rockfishes (Yoklavich \& Boehlert 1987, Laidig \& Sakuma 1998), and we assume daily growth bands in these rockfishes. Otoliths were subsequently photographed using a Lumenera Infinity 2-3C CCD camera. Images were analyzed using Image Premier 7.0 software (Media Cybernetics) to measure the distance between the dorsal edge of otoliths and the 31st growth band, marking the first day of experimentation. This distance guided the laser ablation ICP-MS sampling protocol to ensure that otolith samples were obtained throughout the experimental period. We measured elemental concentrations in a series of adjacent laser spots in a linear transect running from the dorsal edge of each otolith towards the core. The putative dates of experimentation were assigned to each spot location on transects to relate otolith chemistry to water chemistry measured during the same exposure period. Date assignments were determined using 
image analysis on otoliths after laser ablation, which illuminated the 9 replicate laser spots that occurred within the $31 \mathrm{~d}$ experimental period. Each spot in the linear sequence was assigned a 'date of exposure' that corresponded to the midpoint of dates sampled by each laser spot.

\section{Otolith chemical analysis}

Elemental concentrations in fish otoliths were measured using laser ablation ICP-MS. A right or left otolith was haphazardly selected and mounted to a glass slide covered with Crystalbond Mounting Wax (Buehler Brand), which has negligible elemental concentrations (Woodson et al. 2013).

All otolith samples were analyzed at the University of California, Davis, Stable Isotope Laboratory, using a Photon Machines 193-nm UV excimer laser ablation system (Teledyne Photon Machines), equipped with a double-cell HelEx chamber and coupled with an Agilent 7700x quadrupole ICP-MS. ICP-MS settings optimized measurements of ${ }^{138} \mathrm{Ba}^{86}{ }^{86} \mathrm{Sr}^{88} \mathrm{Sr},{ }^{43} \mathrm{Ca},{ }^{44} \mathrm{Ca}$, ${ }^{24} \mathrm{Mg}$ and ${ }^{25} \mathrm{Mg}$ isotopes. Samples received 10 cleaning shots prior to sample ablation to remove any surface contaminants. Background elemental concentrations were recorded for $30 \mathrm{~s}$ before sample ablation to determine limits of detection and to perform drift-corrections. Limits of detection were calculated as 3 times the standard deviation of background levels for each element and expressed as a ratio to $\mathrm{Ca}$ (Table 4). Precision was calculated as the mean RSD of elemental ratios to Ca using the standard NIST 612 (Table 4). The glass standards NIST 610 and 612 were run after every 12th sample for calibration and to correct for instrument drift. Each standard was sampled with 2 replicate $50 \mu \mathrm{m}$ spots with 300 shots at a fluence of $4.45 \mathrm{~J} \mathrm{~cm}^{-2}$, and a repetition rate of $5 \mathrm{~Hz} .{ }^{43} \mathrm{Ca}$ was used as an internal standard, assuming $40.0 \%$ calcium in calcite. Statistical analyses used the mean elemental ratios to ${ }^{43} \mathrm{Ca}$ of replicate spots.

Table 4. Laser ablation inductively coupled plasma mass spectrometry estimates of instrument precision (RSD: relative standard deviation, as \% of mean) and limits of detection (LOD) for element/Ca ratios using the NIST 612 glass standard

\begin{tabular}{|llc|}
\hline Ratio & RSD & LOD \\
\hline $\mathrm{Mg} / \mathrm{Ca}$ & 7.38 & $1.59 \mathrm{mmol} \mathrm{mol}^{-1}$ \\
$\mathrm{Sr} / \mathrm{Ca}$ & 5.25 & $0.154 \mathrm{mmol} \mathrm{mol}^{-1}$ \\
$\mathrm{Ba} / \mathrm{Ca}$ & 0.004 & $0.047 \mu \mathrm{mol} \mathrm{mol}^{-1}$ \\
\hline
\end{tabular}

Laser ablation settings were customized to meet the unique objectives of each experiment while optimizing precision of elemental concentration measurements. In the experiment to resolve otolith partition coefficients at different temperatures, we measured trace element concentrations on the surface of whole otoliths with 2 replicate $150 \mu \mathrm{m}$ diameter laser spots. Each spot was sampled with 300 shots of the laser using a fluence of $1.46 \mathrm{~J} \mathrm{~cm}^{-2}$ and a repetition rate of $5 \mathrm{~Hz}$. To determine whether laser ablation sampled into otolith growth bands preceding the experimental period, we measured the pit depth of a subset of 44 otoliths using a FEI Quanta 450 FEG scanning electron microscope. Mean pit depth was $17.12 \mu \mathrm{m}(\mathrm{SD}=5.31)$. The distance between daily growth bands in juvenile rockfish otoliths ranges from $\sim 2.5$ to $7 \mu \mathrm{m} \mathrm{d}^{-1}$ (measured by Wheeler 2015), which indicates the laser sampled $<10 \mathrm{~d}$ of otolith growth in our experiment. These measurements indicate no mixing of pre-experimental and experimental material during ablation.

In the analysis to evaluate chemistry during an upwelling-relaxation cycle, we sampled 2 replicate $15 \mu \mathrm{m}$ diameter laser spots at each adjacent spot location along transects. Spot sizes represented 3 to $5 \mathrm{~d}$ of the rearing environment and a timescale sufficient to distinguish between upwelling and relaxation conditions. Each replicate spot was sampled with 300 shots at a fluence of $3.54 \mathrm{~J} \mathrm{~cm}^{-2}$ and a repetition rate of $5 \mathrm{~Hz}$.

Elemental ratios to Ca for otoliths were calculated using data reduction protocols outlined by Longerich et al. (1996), which include procedures to detect outliers, correct for instrument drift by bracketing samples with NIST 612, and amend data by subtracting background count rates from each data point. Elemental ratios to $\mathrm{Ca}$ were calculated by normalization to the known trace element concentrations in the drift-corrected bracketed analyses of the NIST 610 standard $\left(\mathrm{Mg}=449 \mu \mathrm{g} \mathrm{g}^{-1}, \mathrm{Sr}=507 \mu \mathrm{g} \mathrm{g}^{-1}, \mathrm{Ba}=451 \mu \mathrm{g}\right.$ $\mathrm{g}^{-1}$ ) (Jochum et al. 2011).

\section{RESULTS}

\section{Seawater chemistry of upwelling-relaxation cycles}

For each year, the hierarchical cluster analyses generated 3 primary groups, which were subsequently characterized as strong upwelling, weak upwelling and relaxation conditions (Fig. 1, Fig. S1 in the Supplement). We categorized the group cluster exhibiting the strongest mean AWS and lowest SST 
as upwelling conditions and the group cluster exhibiting weakest mean AWS and highest SST values as relaxation conditions. The group cluster exhibiting intermediate values was categorized as weak upwelling conditions because AWS with values at or below $-5 \mathrm{~m} \mathrm{~s}^{-1}$ (a negative sign indicates northerly wind) are strong enough to drive upwelling (Roughan et al. 2005). A small number of samples grouped separately from the 3 major clusters in 2010, 2011, and 2012 (2, 3 and 4 samples, respectively). Mean SST and AWS values of these samples were used to classify them into water mass types. Samples in 2010 and 2011 reflected strong upwelling conditions providing reasonable justification to group these samples into the strong upwelling category $\left(2010\right.$ : SST $=9.47^{\circ} \mathrm{C}$, AWS $=-9.21 \mathrm{~m} \mathrm{~s}^{-1} ; 2011:$ SST $=9.57^{\circ} \mathrm{C}$, AWS $=$ $-6.93 \mathrm{~m} \mathrm{~s}^{-1}$ ). Using the same criteria, 3 samples in 2012 were classified as relaxation conditions and 1 sample as strong upwelling conditions $\left(\mathrm{SST}=12.78^{\circ} \mathrm{C}\right.$,

a) Oceanographic conditions

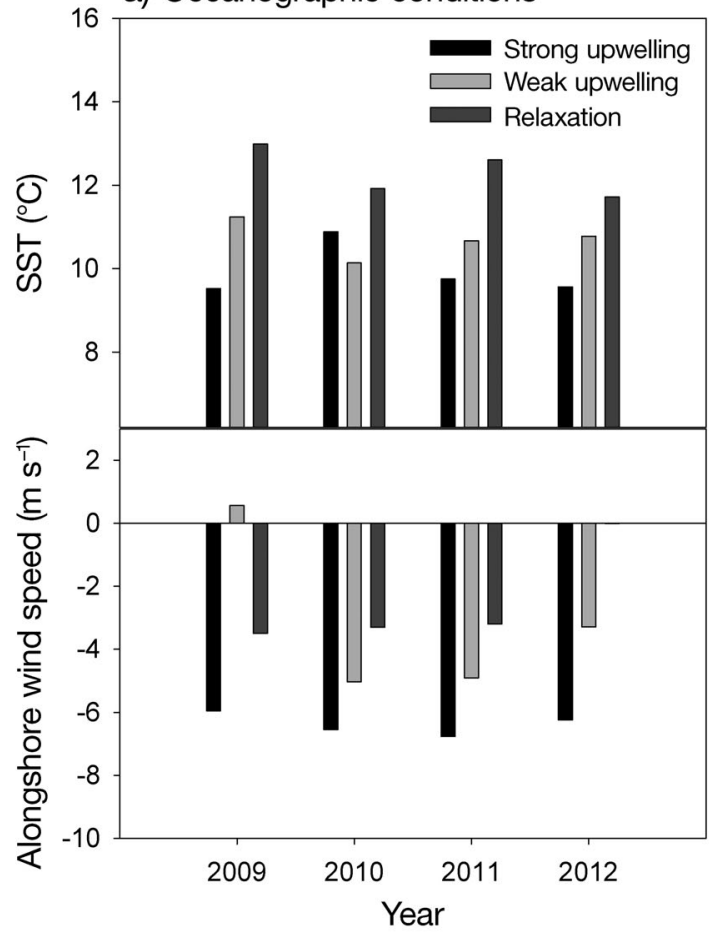

Fig. 1. Water types identified as strong upwelling, weak upwelling, and relaxation by cluster analysis exhibit variation in (a) oceanographic conditions and (b) seawater chemistry. Negative values of alongshore wind speed indicate a northerly wind. SST: sea surface temperature
AWS $=-0.19 \mathrm{~m} \mathrm{~s}^{-1}$ and $\mathrm{SST}=9.31^{\circ} \mathrm{C}, \mathrm{AWS}=-11.53$ $\mathrm{m} \mathrm{s}^{-1}$, respectively).

Seawater chemistry differed among years and water mass types, with no interaction between year and water type (Tables 5 \& 6). Pair-wise comparisons revealed differences between strong upwelling and weak upwelling water mass types, and no difference between strong upwelling and relaxation or between relaxation and weak upwelling water mass types. SIMPER analysis identified the $\mathrm{Ba} / \mathrm{Ca}$ ratio as explaining the highest proportion of the dissimilarity among water masses (Table 7).

\section{Temperature effect on otolith partition coefficients}

We observed no significant temperature dependence for the Sr/Ca ratio in either species, within the uncertainty of our measurements. However, for both

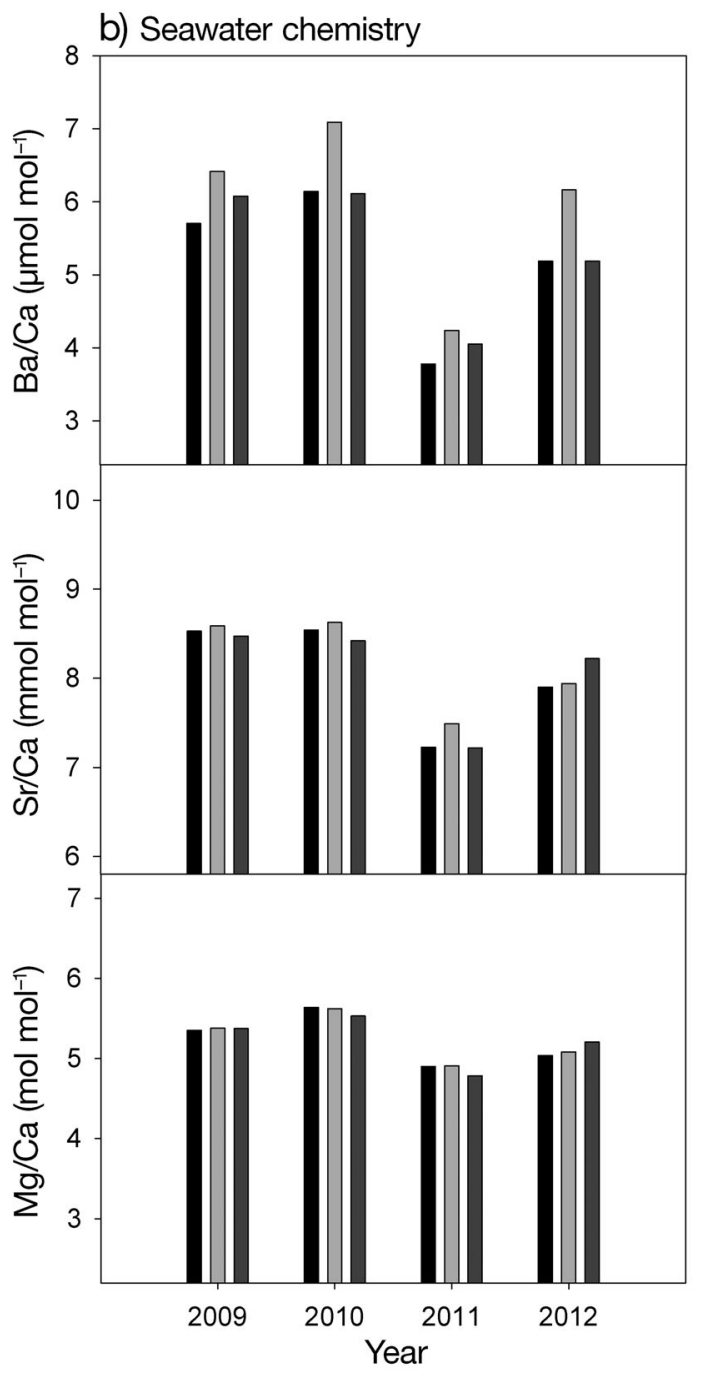


Table 5. Mean, SD (in parentheses), and sample sizes ( $\mathrm{n}$, total $=125)$ based on cluster analyses of seawater $\mathrm{Mg} / \mathrm{Ca}, \mathrm{Sr} / \mathrm{Ca}$, and $\mathrm{Ba} / \mathrm{Ca}$ ratios collected during strong upwelling, weak upwelling, and relaxation conditions in 2009 to 2012

\begin{tabular}{|clcccc|}
\hline Year & Water mass type & $\mathrm{n}$ & $\begin{array}{c}\mathrm{Mg} / \mathrm{Ca} \\
\left(\mathrm{mol} \mathrm{mol}^{-1}\right)\end{array}$ & $\begin{array}{c}\mathrm{Sr} / \mathrm{Ca} \\
\left(\mathrm{mmol} \mathrm{mol}^{-1}\right)\end{array}$ & $\begin{array}{c}\mathrm{Ba} / \mathrm{Ca} \\
\left(\mu \mathrm{mol} \mathrm{mol}{ }^{-1}\right)\end{array}$ \\
\hline 2009 & Strong upwelling & 10 & $5.35(0.16)$ & $8.53(0.20)$ & $5.70(0.63)$ \\
& Weak upwelling & 9 & $5.41(0.21)$ & $8.62(0.18)$ & $6.37(1.09)$ \\
& Relaxation & 9 & $5.35(0.15)$ & $8.46(0.18)$ & $6.15(0.68)$ \\
2010 & Strong upwelling & 16 & $5.70(0.58)$ & $8.63(0.67)$ & $6.24(1.10)$ \\
& Weak upwelling & 8 & $5.62(0.59)$ & $8.63(0.74)$ & $7.09(0.95)$ \\
& Relaxation & 6 & $5.53(0.26)$ & $8.42(0.28)$ & $6.11(0.74)$ \\
2011 & Strong upwelling & 12 & $4.90(0.23)$ & $7.23(0.62)$ & $3.78(1.10)$ \\
& Weak upwelling & 12 & $4.91(0.20)$ & $7.49(0.61)$ & $4.24(1.16)$ \\
& Relaxation & 6 & $4.79(0.15)$ & $7.22(0.67)$ & $4.05(1.33)$ \\
& Strong upwelling & 14 & $5.04(0.07)$ & $7.90(0.30)$ & $5.19(0.45)$ \\
& Weak upwelling & 13 & $5.08(0.14)$ & $7.94(0.22)$ & $6.16(0.98)$ \\
& Relaxation & 10 & $5.20(0.18)$ & $8.22(0.26)$ & $5.19(1.04)$ \\
\hline
\end{tabular}

Table 6. (a) PERMANOVA and (b) post hoc pair-wise comparisons of seawater chemistry among water masses. Significance value is $p<0.05$

\begin{tabular}{|lccccc|}
\hline Source of variation & df & SS & MS & Pseudo- $F$ & p-perm \\
\hline Water Mass Type & 2 & 8.401 & 4.2 & 2.8136 & 0.048 \\
Year & 3 & 163.21 & 54.402 & 34.63 & 0.001 \\
Water Mass Type $\times$ Year & 6 & 5.7536 & 0.95893 & 0.61042 & 0.757 \\
Error & 113 & 177.52 & 1.5707 & & \\
Total & 124 & 372 & & & \\
(b) & & & & & \\
Group & & & $t$ & & 0.753 \\
\hline Strong upwelling, relaxation & & 0.45326 & \\
Strong upwelling, weak upwelling & 2.1882 & \\
Relaxation, weak upwelling & & 1.6807 & & 0.022 \\
\end{tabular}

Table 7. SIMPER analysis comparing the relative contribution (\%) of elemental ratios in explaining the dissimilarity among water mass types

\begin{tabular}{|lccc|}
\hline Group & Mg/Ca (\%) & Sr/Ca (\%) & Ba/Ca (\%) \\
\hline Strong upwelling, relaxation & 34.18 & 32.21 & 33.61 \\
Strong upwelling, weak upwelling & 32.82 & 30.02 & 37.15 \\
Relaxation, weak upwelling & 24.19 & 27.63 & 48.18 \\
\hline
\end{tabular}

species, the distribution coefficients $D_{\mathrm{Mg}}$ and $D_{\mathrm{Ba}}$ were significantly lower at $8.5^{\circ}$ than at $11^{\circ}$ or $14^{\circ} \mathrm{C}$. A 2-factor ANOVA revealed that the effects of temperature on otolith partition coefficients, $D_{\text {Metal }}$ and $D_{\text {Metal }} / \mathrm{SL}$, were element- and species-specific (Table 8, Fig. 2). There was no temperature effect on $D_{\mathrm{Sr}}$ or $D_{\mathrm{Sr}} / \mathrm{SL}$ for either species; however, for both species there was an effect of temperature on $D_{\mathrm{Mg}}$ and $D_{\mathrm{Mg}} / \mathrm{SL}$. Copper and BY rockfish $D_{\mathrm{Mg}}$ was 91 and $83 \%$ lower at $8.5^{\circ} \mathrm{C}$ relative to the 11 and $14^{\circ} \mathrm{C}$ treatments (Tukey's HSD: $\mathrm{p}<0.001$ for both comparisons), and $D_{\mathrm{Mg}}$ did not differ between 11 and $14^{\circ} \mathrm{C}(\mathrm{p}=0.96)$. Similarly, $D_{\mathrm{Mg}} / \mathrm{SL}$ was lower at $8.5^{\circ} \mathrm{C}$ relative to the 11 and $14^{\circ} \mathrm{C}$ treatments $\left(8.5^{\circ} \mathrm{C}, 11^{\circ} \mathrm{C} \mathrm{p}<0.001\right.$ for both comparisons), and $D_{\mathrm{Mg}} / \mathrm{SL}$ did not differ between 11 and $14^{\circ} \mathrm{C}(\mathrm{p}=1.00)$. Species and temperature interacted to affect $D_{\text {Ba }}$ and $D_{\mathrm{Ba}} / \mathrm{SL}$. There was no difference in $D_{\mathrm{Ba}}$ or $D_{\mathrm{Ba}} / \mathrm{SL}$ between species at $8.5^{\circ} \mathrm{C}(\mathrm{p}=0.98$ and $\mathrm{p}=1.00$, respectively). Within each species, $D_{\mathrm{Ba}}$ did not differ between the 11 and $14^{\circ} \mathrm{C}$ treatments, though $D_{\mathrm{Ba}}$ and $D_{\mathrm{Ba}} / \mathrm{SL}$ differed between species at $11^{\circ} \mathrm{C}(\mathrm{p}=0.004$ and $\mathrm{p}=0.002$, respectively) and $14^{\circ} \mathrm{C}(\mathrm{p}=$ 0.002 and $p=0.001$, respectively).

\section{Otolith and seawater chemistry during an upwelling-relaxation cycle}

Seawater and otolith chemistry exhibited considerable variation over the $31 \mathrm{~d}$ experiment. The $\mathrm{Sr} / \mathrm{Ca}_{\text {Seawater }}$ and $\mathrm{Ba} / \mathrm{Ca}_{\text {Seawater }}$ ratios initially reflected upwelling conditions and increased throughout the experimental period as oceanographic conditions transitioned into a relaxation event followed by weak upwelling conditions (Figs. $3 \& 4$ ).

Image analysis of post-ablation otoliths from both species revealed that each laser ablation spot sampled a 3 to $4 \mathrm{~d}$ exposure to ambient experimental conditions. Elemental ratios in otoliths responded rapidly to changes in seawater chemistry. For example, $\mathrm{Ba} / \mathrm{Ca}_{\mathrm{O}}$ tolith increased within $\sim 3 \mathrm{~d}$ following an increase in $\mathrm{Ba} / \mathrm{Ca}_{\text {Seawater }}$ on 26 June, and $\mathrm{Sr} / \mathrm{Ca}_{\mathrm{Otolith}}$ declined following a decrease in $\mathrm{Sr} / \mathrm{Ca}_{\text {Seawater }}$ from 24 June to 10 July in BY rockfish. The relative increases in otolith $\mathrm{Ba} / \mathrm{Ca}$ and $\mathrm{Sr} / \mathrm{Ca}$ ratios were proportional to similar increases in seawater concentrations. Over the experimental period, $\mathrm{Ba} / \mathrm{Ca}_{\text {seawater }}$ increased by a factor of 2.73 and 2.17 in the copper and BY rockfish tanks, respectively, while $\mathrm{Ba} / \mathrm{Ca}_{\text {Otolith }}$ increased by a factor of 3.03 and 2.36 in the copper and BY rockfish, respectively. 
Table 8. ANOVA comparing (a) partition coefficients measured in copper and BY (black and yellowtail species complex) rockfishes reared at $8.5,11$, or $14^{\circ} \mathrm{C}$ and (b) partition coefficients scaled to mean fish standard length (SL) per replicate tank. Significance value is $\mathrm{p}<0.05$

\begin{tabular}{|c|c|c|c|c|c|c|c|}
\hline \multirow[t]{2}{*}{$\begin{array}{l}\text { (a) } \\
\text { Source of variation }\end{array}$} & \multirow[t]{2}{*}{$\mathrm{df}$} & \multicolumn{2}{|c|}{$D_{\mathrm{Mg}}$} & \multicolumn{2}{|c|}{$D_{\mathrm{Sr}}$} & \multicolumn{2}{|c|}{$D_{\text {Ва }}$} \\
\hline & & $F$ & $\mathrm{p}$ & $F$ & $\mathrm{p}$ & $F$ & $\mathrm{p}$ \\
\hline Species & 1,12 & 0.18 & 0.681 & 1.05 & 0.327 & 39.74 & $<0.001$ \\
\hline Temperature & 2,12 & 38.46 & $<0.001$ & 0.59 & 0.567 & 111.27 & $<0.001$ \\
\hline Temperature $\times$ Species & 2,12 & 0.13 & 0.877 & 1.17 & 0.344 & 6.52 & 0.012 \\
\hline \multicolumn{8}{|l|}{ (b) } \\
\hline \multirow[t]{2}{*}{ Source of variation } & \multirow[t]{2}{*}{ df } & \multicolumn{2}{|c|}{$D_{\mathrm{Mg}} / \mathrm{SL}$} & \multicolumn{2}{|c|}{$D_{\mathrm{Sr}} / \mathrm{SL}$} & \multicolumn{2}{|c|}{$D_{\mathrm{Ba}} / \mathrm{SL}$} \\
\hline & & $F$ & $\mathrm{p}$ & $F$ & $\mathrm{p}$ & $F$ & $\mathrm{p}$ \\
\hline Species & 1,12 & 0.001 & 0.981 & 3.26 & 0.096 & 41.86 & $<0.001$ \\
\hline Temperature & 2,12 & 43.90 & $<0.001$ & 1.04 & 0.384 & 51.76 & $<0.001$ \\
\hline Temperature $\times$ Species & 2,12 & 0.24 & 0.790 & 0.52 & 0.610 & 9.13 & 0.004 \\
\hline
\end{tabular}

The range in $\mathrm{Ba} / \mathrm{Ca}_{\text {Otolith }}$ was 1.82 to $11.99 \mu \mathrm{mol} \mathrm{mol} \mathrm{m}^{-1}$ for copper rockfish and 1.99 to $9.77 \mu \mathrm{mol}$ $\mathrm{mol}^{-1}$ for BY rockfish. Minimum $\mathrm{Sr} / \mathrm{Ca}_{\text {Seawater }}$ occurred at the start of the experimental period and was highest when oceanographic conditions reflected relaxation condi-

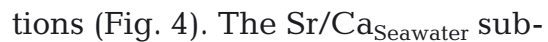
sequently declined to intermediate levels, while Sr/Ca Otolith exhibited moderate synchrony with $\mathrm{Sr} /$ $\mathrm{Ca}_{\text {Seawater }}$ with less temporal variation. When conditions transitioned from upwelling to relaxation condi-

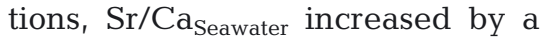
factor of 1.13 in both copper and BY

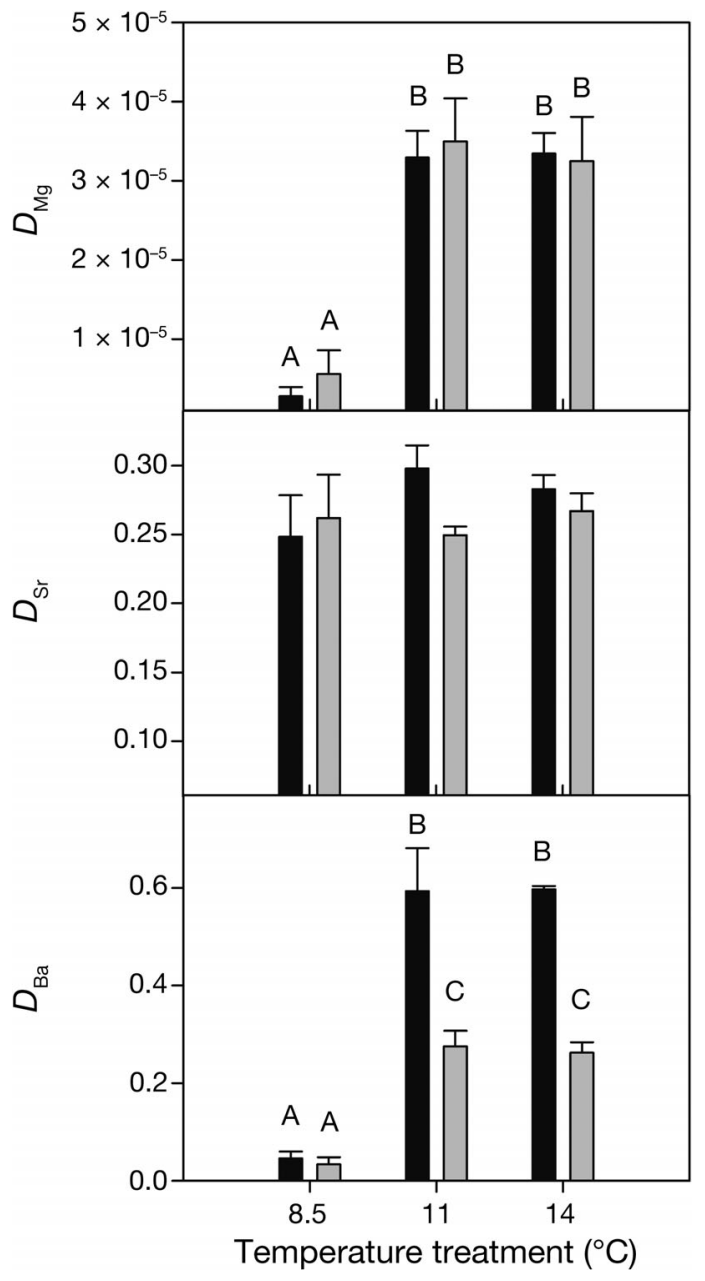

Fig. 2. Otolith partition coefficients $\left(D_{\text {Metal }}\right)$ measured at 8.5, 11 and $14^{\circ} \mathrm{C}$ in copper (black bars) and BY (black and yellowtail species complex) rockfishes (gray bars) in replicate tanks $(n=3)$. Uppercase letters: $p<0.05$ in pairwise comparisons (Tukey's HSD)

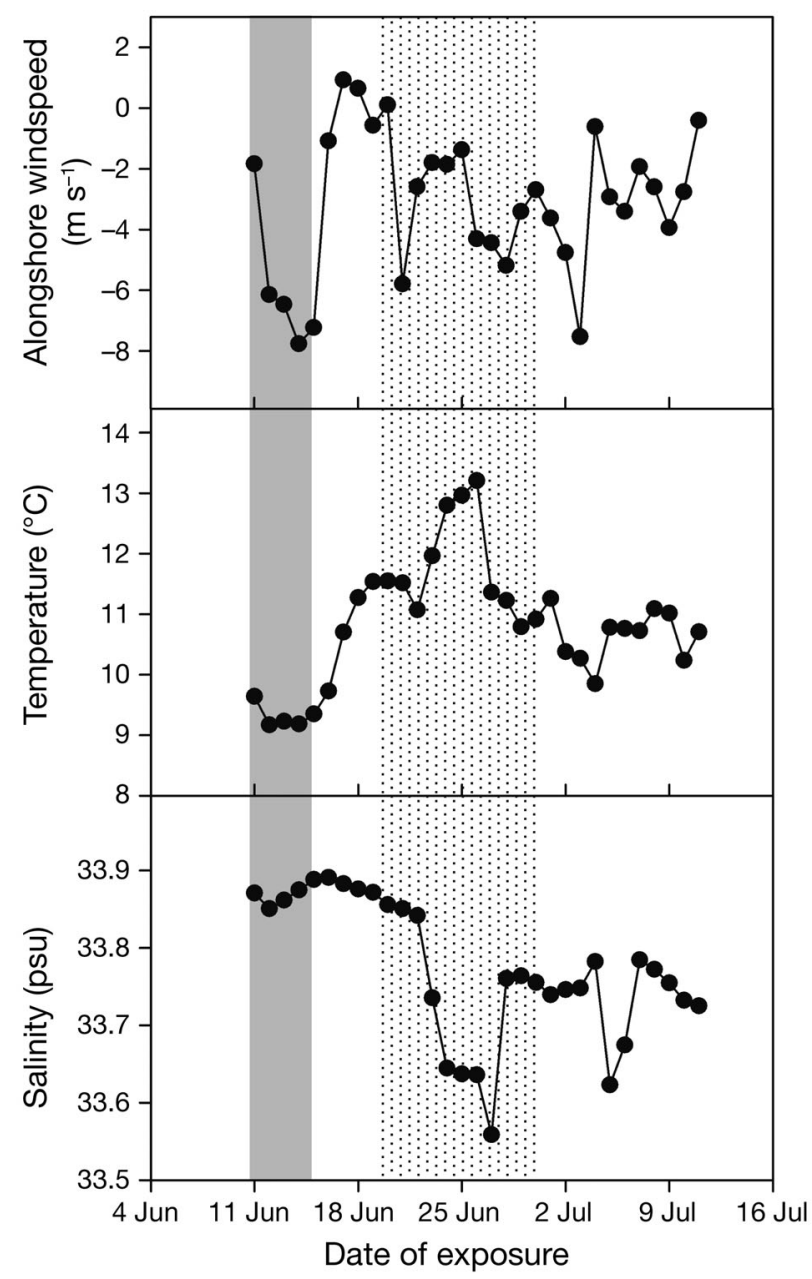

Fig. 3. Oceanographic conditions present during experimental exposure to seawater during an upwelling-relaxation cycle. Gray bar: strong upwelling period; stippled bar: relaxation period 
a) Copper rockfish

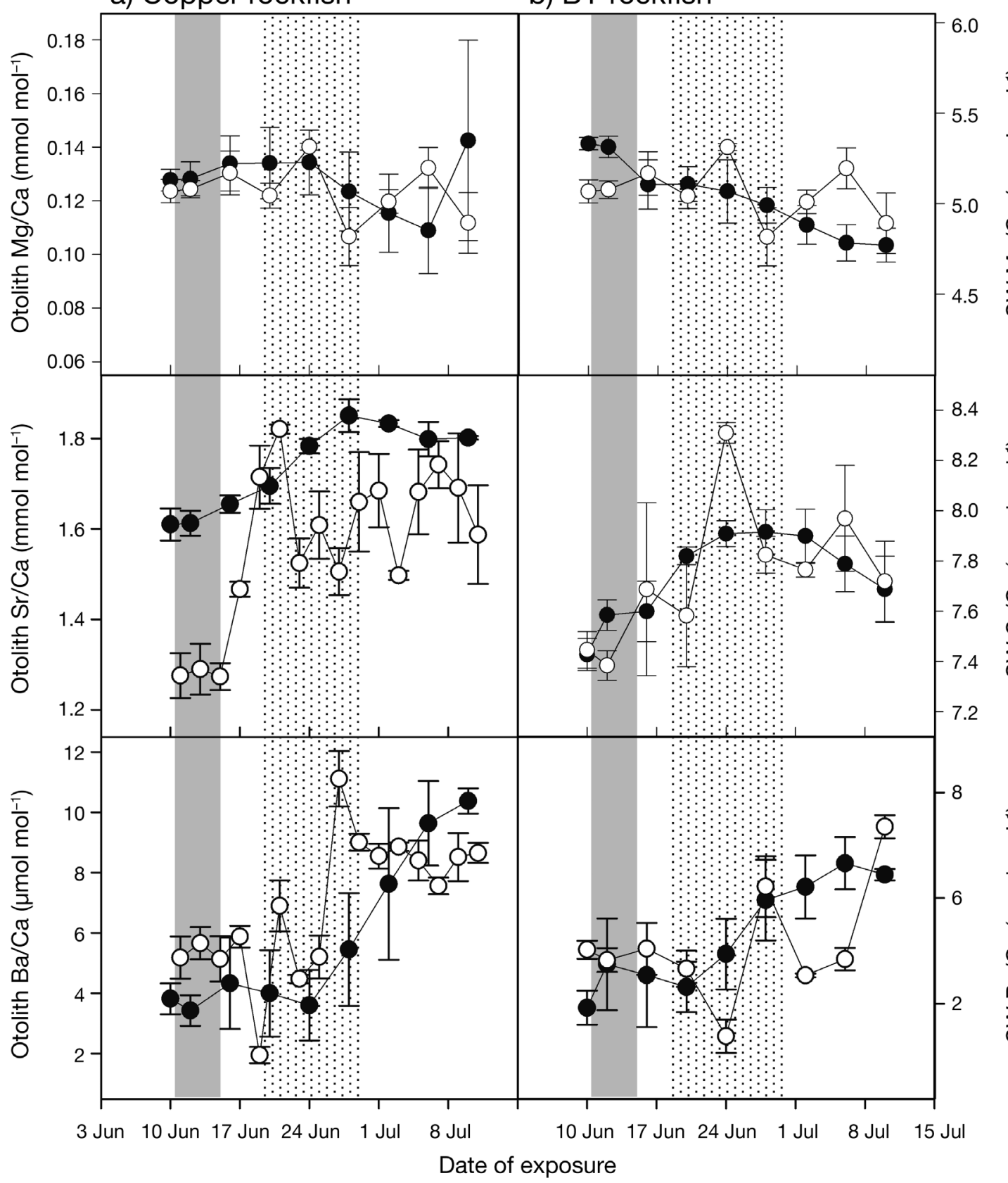

b) BY rockfish

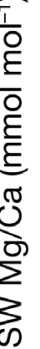

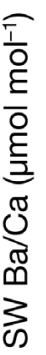

Fig. 4. Otolith (-) and seawater (SW, O) Mg/Ca, Sr/Ca and Ba/Ca ratios for (a) copper rockfish and (b) BY (black and yellowtail species complex) rockfish reared during an upwelling-relaxation cycle. Gray bar: strong upwelling period; stippled bar: relaxation period

rockfish tanks, while $\mathrm{Sr} / \mathrm{Ca}_{\text {Otolith }}$ increased by a factor of 1.15 and 1.12 in copper and BY rockfish tanks, respectively (Fig. 4). Over the entire experimental period, $\mathrm{Sr} / \mathrm{Ca}_{\text {Otolith }}$ ranged from 1.55 to $1.92 \mathrm{mmol}$ $\mathrm{mol}^{-1}$ for copper rockfish and 1.49 to $1.75 \mathrm{mmol} \mathrm{mol}^{-1}$ for BY rockfish. We detected minimal variability in $\mathrm{Mg} / \mathrm{Ca}_{\text {Seawater }}$ and $\mathrm{Mg} / \mathrm{Ca}_{\text {Otolith, with no observable }}$ change associated with changing oceanographic conditions. The range in $\mathrm{Mg} / \mathrm{Ca}_{\text {Otolith }}$ was 0.08 to $0.15 \mathrm{mmol} \mathrm{mol}^{-1}$ for copper rockfish and 0.09 to $0.15 \mathrm{mmol} \mathrm{mol}^{-1}$ for BY rockfish. Copper and BY rockfish otolith chemistry corresponded to changing seawater and oceanographic conditions in a similar manner. 


\section{DISCUSSION}

Understanding chemical proxies of upwellingrelaxation cycles is valuable for interpreting variability of trace elements in the marine environment and for the potential application of chemical signatures to the study of marine fish movement. We provide evidence that trace element signatures in seawater vary across upwelling-relaxation cycles, with weak upwelling events exhibiting a unique elemental signature in coastal water samples collected over $4 \mathrm{yr}$. However, seawater signatures differed significantly among years, which indicates that interannual variation must be considered when using otolith chemistry to evaluate movement in this system. We found a significant effect of temperature on the partitioning of $\mathrm{Mg}$ and $\mathrm{Ba}$ into otoliths for juvenile rockfishes, providing the information needed to interpret otolith elemental ratios in a coastal upwelling region. We employed a unique approach to evaluate otolith chemistry as a tool to reconstruct movement of juvenile rockfish by exposing fish to naturally variable conditions during an upwelling-relaxation cycle. The subsequent analyses of otolith and seawater chemistry validated laser ablation ICP-MS as an effective method to measure variability in otolith chemistry over ecologically relevant time scales and environmental conditions.

This research contributes to the limited number of studies characterizing elemental signatures of waters in a coastal upwelling region over multiple years (van Geen \& Husby 1996, Takesue \& van Geen 2002). PERMANOVA analysis demonstrated that waters associated with weak upwelling conditions show distinct $\mathrm{Mg} / \mathrm{Ca}, \mathrm{Sr} / \mathrm{Ca}$, and $\mathrm{Ba} / \mathrm{Ca}$ ratios relative to strong upwelling and relaxation conditions. Elevated $\mathrm{Ba} / \mathrm{Ca}$ ratios characterized waters during weak upwelling conditions relative to the other water types. Although strong upwelling water mass types exhibited a lower $\mathrm{Ba} / \mathrm{Ca}$ ratio relative to weak upwelling conditions, its magnitude was equivalent to measurements by Woodson et al. (2013) in nearby locations with persistent upwelling conditions. In addition, surface salinities measured during weak upwelling and relaxation conditions were $\sim 0$ to $0.35 \mathrm{psu}$ lower than upwelled surface waters and likely contained a greater contribution of high-Ba river runoff. Therefore, the $\mathrm{Ba} / \mathrm{Ca}$ ratio of coastal water masses is likely a product of complex mixing processes.

We observed significant interannual differences in $\mathrm{Mg} / \mathrm{Ca}, \mathrm{Sr} / \mathrm{Ca}$, and $\mathrm{Ba} / \mathrm{Ca}$ ratios, with the highest ratios occurring in 2010 and the lowest in 2011. Year did not interact with water type, indicating that the rela- tive differences in the chemical signatures of water types exhibited a similar relationship within each year. Interannual variability is likely due to differences in mixing and stratification, which influence the delivery of deep waters with characteristic elemental ratios as well as nutrients. In 2011, a warmer mixed layer was observed off Point Reyes, and alongshore flows ceased in the summer (Bjorkstedt et al. 2011, Jones \& Mulligan 2014). Increased stratification in 2011 likely reduced the input of deeper water and its chemical fingerprint and nutrient content, and suppressed plankton blooms, which might otherwise have removed $\mathrm{Sr}$ and $\mathrm{Ba}$ from the surface. Our results indicate that elemental signatures of coastal water masses must be evaluated yearly to accurately interpret these signatures and adequately characterize water samples as they relate to upwelling dynamics.

We found elevated $\mathrm{Ba} / \mathrm{Ca}$ was the strongest indicator for weak upwelling relative to other water types in each year. Seawater $\mathrm{Mg} / \mathrm{Ca}$ and $\mathrm{Sr} / \mathrm{Ca}$ ratios exhibited minimal variation among water types, which suggests that they may not serve as valuable proxies for oceanographic conditions as individual ratios; however, our multivariate analysis demonstrated that when $\mathrm{Ba} / \mathrm{Ca}, \mathrm{Sr} / \mathrm{Ca}$ and $\mathrm{Mg} / \mathrm{Ca}$ ratios are evaluated together, they exhibit sufficient variation among water types to distinguish weak upwelling from relaxation or strong upwelling conditions. Thus, this combination of ratios can potentially be used to make inferences about associations of marine organisms with water masses in coastal environments. Future studies that evaluate seawater chemistry at multiple sites and over several years could provide insight into the spatial and temporal consistency of chemical signatures.

\section{Temperature effect on otolith partition coefficients}

Understanding the factors that affect the incorporation of elements into otoliths can help in interpreting their concentrations. Our results are consistent with previous research indicating that species-specific temperature effects can influence partition coefficients for metals such as Ba and $\mathrm{Mg}$, confirming the need for validation studies prior to interpreting values in wild-caught fish (Elsdon \& Gillanders 2002, 2003, Bath Martin et al. 2004, Miller 2009, 2011). Our observation that there was no temperature effect on $D_{\mathrm{Sr}}$ for either species contrasts with the behavior of the $\mathrm{Sr} / \mathrm{Ca}$ ratio in biogenic aragonite in different taxa observed by others (Shen et al. 1996, Elsdon \& Gillanders 2002, Zacherl et al. 2003, Bath Martin et al. 
2004), which may be explained by the magnitude and relatively narrow temperature range tested in our study. These differences highlight a need for more investigation into the biological control over $\mathrm{Sr}$ incorporation that is exerted by different kinds of organisms.

Our results suggest that there may be a physiological threshold between 8.5 and $11^{\circ} \mathrm{C}$, affecting $\mathrm{Mg}$ and $\mathrm{Ba}$ incorporation into otoliths. These results are consistent with previous studies suggesting that physiological regulation controls $\mathrm{Mg}$ (and possibly $\mathrm{Ba}$ ) concentration in otoliths, rather than diet or ambient seawater Mg concentrations (Woodcock et al. 2012). The primary pathway of elements into otoliths is entry into the blood plasma via the gills or intestine, followed by cellular transport into the endolymph fluid and subsequent crystallization (Campana 1999). Physiological filters between water and otoliths occur due to osmoregulation and during cellular transport into the endolymph (Townsend et al. 1992, Campana 1999). Reduced ability to discriminate against Ba during entry into the endolymph has been postulated to occur at lower temperatures for juveniles of the black bream Acanthopagrus butcheri (Elsdon \& Gillanders $2002,2003)$; however, species may differ in their responses to temperature, because the related physiological processes are likely species-specific (Bath et al. 2000, Elsdon \& Gillanders 2003). Miller (2009) found lower $D_{\mathrm{Ba}}$ values at $7.4^{\circ} \mathrm{C}$ than at $13^{\circ} \mathrm{C}$ in the black rockfish $S$. melanops, which may be a consequence of differences in seawater concentrations or experimental conditions. The range of $D_{\mathrm{Ba}}$ measured by Miller (2009), however, spans a similar range to that measured in this study. The $D_{\mathrm{Ba}}$ values we measured at 11 and $14^{\circ} \mathrm{C}$ are generally higher relative to other species (see review in Table 1 of Miller 2009), though $D_{\mathrm{Ba}}$ as high as $1.23 \mu \mathrm{mol} \mathrm{mol}{ }^{-1}$ has been observed by others in early juveniles of the spot Leiostomus xanthurus (Bath Martin \& Thorrold 2005). Species-specific physiological processes and experimental conditions may explain the range of $D_{\mathrm{Ba}}$ values measured among fishes.

Temperature effects are important considerations when estimating $\mathrm{Mg} / \mathrm{Ca}_{\text {Otolith }}$ or $\mathrm{Ba} / \mathrm{Ca}_{\text {Otolith }}$ from ambient water chemistry or vice versa. For example, the utility of $\mathrm{Ba} / \mathrm{Ca}_{\text {Otolith }}$ as a proxy for coastal water masses may depend on knowledge of SST. In coastal environments under strong upwelling conditions, when upwelled waters are simultaneously cold and exhibit low $\mathrm{Ba} / \mathrm{Ca}$ ratios relative to those found under weak upwelling conditions, a temperature-related reduction in $D_{\mathrm{Ba}}$ may only enhance the function of low $\mathrm{Ba} / \mathrm{Ca}_{\text {Otolith }}$ as a proxy for strong upwelling by reducing an already low $\mathrm{Ba} / \mathrm{Ca}_{\text {Otolith. A temperature }}$ effect, however, may mask upwelling signatures in offshore environments disconnected from terrigenous or estuarine sources of Ba. For example, Woodson et al. (2013) measured higher $\mathrm{Ba} / \mathrm{Ca}_{\text {Seawater }}$ in samples collected $\sim 10-70 \mathrm{~km}$ offshore from locations with strong upwelling conditions. A temperature effect on $D_{\mathrm{Ba}}$ has the potential to reduce the $\mathrm{Ba} / \mathrm{Ca}$ ratio in otoliths formed during strong upwelling events and, thus, limit the ability of $\mathrm{Ba} / \mathrm{Ca}_{\text {Otolith }}$ to distinguish between fish residing in different water masses. Reconstructing upwelling water mass associations of fish residing in offshore systems may be more complex and would benefit from further validation studies and additional geochemical proxies, such as oxygen isotopes $\left(\delta^{18} \mathrm{O}\right)$.

\section{Otolith and seawater chemistry during an upwelling-relaxation cycle}

Evaluating the ability of otolith analysis to capture temporal variability in seawater over naturally variable oceanographic conditions is essential for determining the extent to which otolith chemistry reflects short-term water mass associations in coastal upwelling regions. We found that elemental ratios in otoliths respond rapidly (within $3 \mathrm{~d}$ ) to changes in seawater chemistry. However, the otolith chemistry obtained from laser analysis likely averages ambient conditions over a longer time period (3-9 d), as seawater elemental ratios were more variable than those observed in the otoliths. These results agree with previous studies finding that it takes days to weeks for otolith elemental ratios to stabilize and reach equilibrium with ambient water concentrations (Elsdon \& Gillanders 2005, Miller 2011). Advances in laser ablation ICP-MS technology may improve the temporal resolution of otolith chemical signals and their ecological interpretation.

By exposing fish to naturally variable conditions, we found that otolith chemistry reflects these changing conditions over an ecologically relevant time scale. During upwelling, $\mathrm{Ba} / \mathrm{Ca}_{\text {Seawater }}$ and $\mathrm{Ba} / \mathrm{Ca}_{\text {Otolith }}$ were at a minimum and increased throughout the experiment as oceanographic conditions transitioned into relaxation and weak upwelling. The relative increases in otolith $\mathrm{Ba} / \mathrm{Ca}$ and $\mathrm{Sr} / \mathrm{Ca}$ ratios were proportional to similar increases in seawater concentrations reflective of changing upwelling strength. The experimental seawater reflected conditions of water mass types characterized from 2009-2012 water samples. We detected variability in $\mathrm{Sr} / \mathrm{Ca}_{\text {Seawater }}$ and 
$\mathrm{Sr} / \mathrm{Ca}_{\text {Otolith, }}$ with peak ratios occurring during relaxation conditions. Higher $\mathrm{Sr} / \mathrm{Ca}_{\text {Seawater }}$ during our experiment is consistent with values measured in coastal water samples collected in the same year, which showed that relaxation water had a higher $\mathrm{Sr} / \mathrm{Ca}$ ratio relative to the other water types. We did not detect lower $\mathrm{Ba} / \mathrm{Ca} \mathrm{atolith}_{\text {or }} \mathrm{Mg} / \mathrm{Ca} \mathrm{atolith}_{\text {when }}$ the water temperature was lowest $\left(9.18^{\circ} \mathrm{C}\right)$ during the experimental period, suggesting that the temperature threshold for a reduction in otolith partition coefficients is between 8 and $9.18^{\circ} \mathrm{C}$. We recommend that future studies consider the potential effect of shortand long-term temperature exposure on $D_{\mathrm{Mg}}$ and $D_{\mathrm{Ba}}$ to improve ecological interpretation of $\mathrm{Mg} / \mathrm{Ca}$ and $\mathrm{Ba} / \mathrm{Ca}$ ratios recorded in otoliths.

Coastal upwelling has long been recognized as a critical factor influencing the survival of fish and invertebrate larvae and the recruitment to adult populations (Parrish et al. 1981, Morgan et al. 2009a,b, 2012, Caselle et al. 2010b, Laidig 2010). There are few existing techniques to tag or reconstruct larval histories in the marine environment, highlighting the need to assess otolith microchemistry as a tool to describe residence of early life-stage fish in coastal upwelling water mass types. This study takes an important step in understanding the chemical signatures of an upwelling region and the potential application of these signatures to study early life-stage marine fishes. We identify the $\mathrm{Ba} / \mathrm{Ca}$ ratio as a promising indicator of coastal upwelling water masses. We also show that the incorporation of $\mathrm{Ba} / \mathrm{Ca}$ into otoliths is reduced below $9^{\circ} \mathrm{C}$ and recommend caution in interpreting chemical signatures in wild fish that may experience cold temperatures. Variability in otolith chemistry reflected similar proportional changes measured in seawater over an upwelling-relaxation cycle. We conclude that seawater and otolith chemical signatures are promising tools to make inferences about the residences of the early life stages of fishes in upwelling regions when coupled with annual water mass signature validation studies. Successful reconstruction of larval histories in coastal water masses calls for a thorough understanding of the factors that may influence temporal and spatial variability in chemical proxies in seawater and otoliths. These environmental factors include the uptake of elements via biological activity, mixing processes, and the influence of external factors on the incorporation of elements into otoliths. Laboratory validation studies in combination with field studies are needed to fully evaluate the complex environmental, physiological, and chemical interactions influencing otolith chemical signatures and their applications.
Acknowledgements. We thank Dr. Seth Miller for contributing 2009 and 2010 seawater samples and providing feedback on the experimental design. We acknowledge Dr. Tessa Hill and Dr. Michéle LaVigne for providing laboratory space and assistance with sample preparation. We thank Dr. Todd Anderson for providing feedback on the manuscript. We also thank the Joint Doctoral Program in Ecology at San Diego State University, the Diablo Valley Fly Fisherman's Club, and the Orange County Fly Fisherman's Club for their financial support. This manuscript is a contribution of the Bodega Marine Laboratory, University of California at Davis.

\section{LITERATURE CITED}

Bakun A, Nelson CS (1991) The seasonal cycle of windstress curl in subtropical eastern boundary current regions. J Phys Oceanogr 21:1815-1834

Bath GE, Thorrold SR, Jones CM, Campana SE, McLaren JW, Lam JWH (2000) Strontium and barium uptake in aragonitic otoliths of marine fish. Geochim Cosmochim Acta 64:1705-1714

Bath Martin G, Thorrold SR (2005) Temperature and salinity effects on magnesium, manganese, and barium incorporation in otolith of larval and early juvenile spot Leiostomus xanthurus. Mar Ecol Prog Ser 293:223-232

Bath Martin G, Thorrold SR, Jones CM (2004) Temperature and salinity effects on strontium incorporation in otoliths of larval spot (Leiostomus xanthurus). Can J Fish Aquat Sci 61:34-42

Bjorkstedt EP, Goericke R, McClatchie S, Weber E and others (2011) State of the California Current 2010-2011: regionally variable responses to a strong (but fleeting?) La Niña. CCOFI Rep 52:36-68

Campana SE (1999) Chemistry and composition of fish otoliths: pathways, mechanisms and applications. Mar Ecol Prog Ser 188:263-297

> Campana SE, Thorrold SR (2001) Otoliths, increments, and elements: keys to a comprehensive understanding of fish populations? Can J Fish Aquat Sci 58:30-38

Caselle JE, Carr MH, Malone DP, Wilson JR, Wendt DE (2010a) Can we predict interannual and regional variation in delivery of pelagic juveniles to nearshore populations of rockfishes (genus Sebastes) using simple proxies of ocean conditions? CCOFI Rep 51:91-105

Caselle JE, Kinlan BP, Warner RR (2010b) Temporal and spatial scales of influence on nearshore fish settlement in the Southern California Bight. Bull Mar Sci 86:355-385

Chan LH, Edmond JM, Stallard RF, Broecker WS, Chung YC, Weiss RF, Ku TL (1976) Radium and barium at GEOSECS stations in the Atlantic and Pacific. Earth Planet Sci Lett 32:258-267

> Coffey M, Dehairs F, Collette O, Luther G, Church T, Jickells $\mathrm{T}$ (1997) The behaviour of dissolved barium in estuaries. Estuar Coast Shelf Sci 45:113-121

Colbert D, McManus J (2005) Importance of seasonal variability and coastal processes on estuarine manganese and barium cycling in a Pacific Northwest estuary. Cont Shelf Res 25:1395-1414

> Cushing DH (1990) Plankton production and year-class strength in fish populations: an update of the match mismatch hypothesis. Adv Mar Biol 26:249-293

> de Villiers S (1999) Seawater strontium and Sr/Ca variability in the Atlantic and Pacific oceans. Earth Planet Sci Lett 171:623-634 
de Villiers S, Nelson BK (1999) Detection of low-temperature hydrothermal fluxes by seawater $\mathrm{Mg}$ and $\mathrm{Ca}$ anomalies. Science 285:721-723

Elsdon TS, Gillanders BM (2002) Interactive effects of temperature and salinity on otolith chemistry: challenges for determining environmental histories of fish. Can J Fish Aquat Sci 59:1796-1808

> Elsdon TS, Gillanders BM (2003) Reconstructing migratory patterns of fish based on environmental influences on otolith chemistry. Rev Fish Biol Fish 13:217-235

Elsdon TS, Gillanders BM (2005) Consistency of patterns between laboratory experiments and field collected fish in otolith chemistry: an example and applications for salinity reconstructions. Mar Freshw Res 56:609-617

> Elsdon TS, Gillanders BM (2006) Temporal variability in strontium, calcium, barium, and manganese in estuaries: implications for reconstructing environmental histories of fish from chemicals in calcified structures. Estuar Coast Shelf Sci 66:147-156

> Elsdon TS, Wells BK, Campana SE and others (2008) Otolith chemistry to describe movements and life-history parameters of fishes: hypotheses, assumptions, limitations and inferences. Oceanogr Mar Biol Annu Rev 46:297-332

Esser BK, Volpe AM (2002) At-sea high-resolution chemical mapping: extreme barium depletion in North Pacific surface water. Mar Chem 79:67-79

García-Reyes M, Largier JL (2012) Seasonality of coastal upwelling off central and northern California: new insights, including temporal and spatial variability. J Geophys Res 117:C03028, doi:10.1029/2011JC007629

Gillanders BM (2005) Otolith chemistry to determine movements of diadromous and freshwater fish. Aquat Living Resour 18:291-300

Griffith EM, Paytan A (2012) Barite in the ocean: occurrence, geochemistry and palaeoceanographic applications. Sedimentology 59:1817-1835

Hamilton SL, Warner RR (2009) Otolith barium profiles verify the timing of settlement in a coral reef fish. Mar Ecol Prog Ser 385:237-244

> Hamilton SL, Regetz J, Warner RR (2008) Postsettlement survival linked to larval life in a marine fish. Proc Natl Acad Sci USA 105:1561-1566

> Hoover RR, Jones CM, Grosch CE (2012) Estuarine ingress timing as revealed by spectral analysis of otolith life history scans. Can J Fish Aquat Sci 69:1266-1277

> Houde ED (2008) Emerging from Hjort's shadow. J Northwest Atl Fish Sci 41:53-70

> Hunter KA, Boyd P (1999) Biogeochemistry of trace metals in the ocean. Mar Freshw Res 50:739-753

> Jochum KP, Weis U, Stoll B, Kuzmin D and others (2011) Determination of reference values for NIST SRM 610-617 glasses following ISO guidelines. Geostand Geoanal Res 35:397-429

Jones MK, Mulligan T (2014) Juvenile rockfish recruitment in Trinidad Bay, California. Trans Am Fish Soc 143: $543-551$

Kalish J (1992) Formation of a stress-induced chemical check in fish otoliths. J Exp Mar Biol Ecol 162:265-277

Kingsford MJ, Hughes JM, Patterson HM (2009) Otolith chemistry of the non-dispersing reef fish Acanthochromis polyacanthus: cross-shelf patterns from the central Great Barrier Reef. Mar Ecol Prog Ser 377:279-288

Laidig TE (2010) Influence of ocean conditions on the timing of early life history events for blue rockfish (Sebastes mystinus) off California. Fish Bull 108:442-449
Laidig TE, Sakuma KM (1998) Description of pelagic larval and juvenile grass rockfish, Sebastes rastrelliger (family Scorpaenidae), with an examination of age and growth. Fish Bull 96:788-796

Lea DW, Shen GT, Boyle EA (1989) Coralline barium records temporal variability in equatorial Pacific upwelling. Nature 340:373-376

Li YH, Chan LH (1979) Desorption of Ba and Ra-226 from river-borne sediments in the Hudson estuary. Earth Planet Sci Lett 43:343-350

Lin YT, Wang CH, You CF, Tzeng WN (2013) Ba/Ca ratios in otoliths of southern bluefin tuna (Thunnus maccoyii) as a biological tracer of upwelling in the Great Australian Bight. J Mar Sci Technol 21:733-741

> Longerich HP, Jackson SE, Gunther D (1996) Laser ablation inductively coupled plasma mass spectrometric transient signal data acquisition and analyte concentration calculation. J Anal At Spectrom 11:899-904

Love MS, Yoklavich MM, Thorsteinson L (2002) The rockfishes of the Northeast Pacific. University of California Press, Berkeley, CA

> Miller JA (2009) The effects of temperature and water concentration on the otolith incorporation of barium and manganese in black rockfish Sebastes melanops. J Fish Biol 75:39-60

Miller JA (2011) Effects of water temperature and barium concentration on otolith composition along a salinity gradient: implications for migratory reconstructions. J Exp Mar Biol Ecol 405:42-52

> Mohan J, Rahman MS, Thomas P, Walther B (2014) Influence of constant and periodic experimental hypoxic stress on Atlantic croaker otolith chemistry. Aquat Biol 20:1-11

> Monnin C, Jeandel C, Cattaldo T, Dehairs F (1999) The marine barite saturation state of the world's oceans. Mar Chem 65:253-261

> Moore WS, Shaw TJ (2008) Fluxes and behavior of radium isotopes, barium, and uranium in seven Southeastern US rivers and estuaries. Mar Chem 108:236-254

Morgan SG, Fisher JL, Mace AJ (2009a) Larval recruitment in a region of strong, persistent upwelling and recruitment limitation. Mar Ecol Prog Ser 394:79-99

> Morgan SG, Fisher JL, Miller SH, McAfee ST, Largier JL (2009b) Nearshore larval retention in a region of strong upwelling and recruitment limitation. Ecology 90: 3489-3502

> Morgan SG, Fisher JL, McAffer ST, Largier JL, Halle CM (2012) Limited recruitment during relaxation events: larval advection and behavior in an upwelling system. Limnol Oceanogr 57:457-470

> Morse JW, Bender ML (1990) Partition coefficients in calcite: examination of factors influencing the validity of experimental results and their application to natural systems. Chem Geol 82:265-277

Nishimoto MM, Washburn L, Warner RR, Love MS, Paradis GL (2010) Otolith elemental signatures reflect residency in coastal water masses. Environ Biol Fishes 89:341-356

Parrish RH, Nelson CS, Bakun A (1981) Transport mechanisms and the reproductive success of fishes in the California Current. Biol Oceanogr 1:175-203

Patterson HM, Kingsford MJ, McCulloch MT (2004) The influence of oceanic and lagoonal plume waters on otolith chemistry. Can J Fish Aquat Sci 61:898-904

Pilson M (2013) An introduction to the chemistry of the sea, 2nd edn. Cambridge University Press, New York, NY

> Robertson DR, Swearer SE, Kaufmann K, Brothers EB (1999) 
Settlement vs. environmental dynamics in a pelagicspawning reef fish at Caribbean Panama. Ecol Monogr 69:195-218

Roughan M, Mace AJ, Largier JL, Morgan SG, Fisher JL, Carter ML (2005) Subsurface recirculation and larval retention in the lee of a small headland: a variation of the upwelling shadow theme. J Geophys Res Oceans 110: C10027, doi:10.1029/2005JC002898

Shen C, Lee T, Chen C, Wang C, Dai C, Li L (1996) The calibration of $D[\mathrm{Sr} / \mathrm{Ca}]$ versus sea surface temperature relationship for Porites corals. Geochim Cosmochim Acta 60: 3849-3858

Sturrock AM, Trueman CN, Darnaude AM, Hunter E (2012) Can otolith elemental chemistry retrospectively track migrations in fully marine fishes? J Fish Biol 81:766-795

Sturrock AM, Trueman CN, Milton JA, Waring CP, Cooper MJ, Hunter E (2014) Physiological influences can outweigh environmental signals in otolith microchemistry research. Mar Ecol Prog Ser 500:245-264

Swearer SE, Caselle JE, Lea DW, Warner RR (1999) Larval retention and recruitment in an island population of a coral-reef fish. Nature 402:799-802

Takesue RK, van Geen A (2002) Nearshore circulation during upwelling inferred from the distribution of dissolved cadmium off the Oregon coast. Limnol Oceanography 47:176-185

Thorrold SR, Zacherl DC, Levin LA (2007) Population connectivity and larval dispersal using geochemical signatures in calcified structures. Oceanography 20:80-89

Townsend DW, Radtke RL, Corwin S, Libby DA (1992) Strontium:calcium ratios in juvenile Atlantic herring Clupea harengus L. otoliths as a function of water temperature. J Exp Mar Biol Ecol 160:131-140

Tsunogai S, Watanabe Y (1981) Calcium in the North Pacific water and the effect of organic matter on the calciumalkalinity relation. Geochem J 15:95-107

Editorial responsibility: Stylianos Somarakis, Heraklion, Greece van Geen A, Husby DM (1996) Cadmium in the California current system: Tracer of past and present upwelling. J Geophys Res 101:3489-3507

> Volpe AM, Esser BK (2002) Real-time ocean chemistry for improved biogeochemical observation in dynamic coastal environments. J Mar Syst 36:51-74

> Walther BD, Thorrold SR (2006) Water, not food, contributes the majority of strontium and barium deposited in the otoliths of a marine fish. Mar Ecol Prog Ser 311:125-130

> Walther BD, Kingsford MJ, O'Callaghan MD, McCulloch MT (2010) Interactive effects of ontogeny, food ration and temperature on elemental incorporation in otoliths of a coral reef fish. Environ Biol Fishes 89:441-451

> Walther BD, Kingsford M, McCulloch MT (2013) Environmental records from Great Barrier Reef corals: inshore versus offshore drivers. PLoS One 8:e77091

Wheeler SG (2015) Biological and oceanographic drivers of larval growth, settlement and recruitment of rockfishes (Sebastes spp.) PhD thesis. University of California, Davis, and San Diego State University, CA

Woodcock SH, Munro AR, Crook DA, Gillanders BM (2012) Incorporation of magnesium into fish otoliths: determining contribution from water and diet. Geochim Cosmochim Acta 94:12-21

> Woodson LE, Wells BK, Grimes CB, Franks RP, Santora JA, Carr MH (2013) Water and otolith chemistry identify exposure of juvenile rockfish to upwelled waters in an open coastal system. Mar Ecol Prog Ser 473:261-273

Yoklavich MM, Boehlert GW (1987) Daily growth increments in otoliths of juvenile black rockfish Sebastes melanops: an evaluation of autoradiography as a new method of validation. Fish Bull 85:826-832

- Zacherl DC, Paradis G, Lea DW (2003) Barium and strontium uptake into larval protoconchs and statoliths of the marine neogastropod Kelletia kelledi. Geochim Cosmochim Acta 67:4091-4099

Submitted: June 18, 2015; Accepted: March 21, 2016

Proofs received from author(s): May 1, 2016 